Review

\title{
P2X receptor-mediated purinergic sensory pathways to the spinal cord dorsal horn
}

\author{
Jianguo G. Gu \& Marc W. Heft \\ Department of Oral and Maxillofacial Surgery and Diagnostic Sciences, McKnight Brain Institute and College of \\ Dentistry, University of Florida, Gainesville, Florida, USA
}

Received 26 August 2004; accepted in revised form 11 October 2004

Key words: ATP, P2X receptors, pain, primary afferent fibers, purinergic, spinal cord dorsal horn, synaptic transmission

\begin{abstract}
P2X receptors are expressed on different functional groups of primary afferent fibers. P2X receptor-mediated sensory inputs can be either innocuous or nociceptive, depending on which dorsal horn regions receive these inputs. We provide a brief review of P2X receptor-mediated purinergic sensory pathways to different regions in the dorsal horn. These P2X purinergic pathways are identified in normal animals, which provides insights into their physiological functions. Future studies on P2X purinergic pathways in animal models of pathological conditions may provide insights on how $\mathrm{P} 2 \mathrm{X}$ receptors play a role in pathological pain states.
\end{abstract}

Abbreviations: ATP-adenosine 5'-triphosphate; DH-dorsal horn; DRG-dorsal root ganglion; EPSCs-excitatory postsynaptic currents; mEPSCs - miniature excitatory postsynaptic currents; VR1 - vanilloid receptor subtype 1

\section{$P 2 X$ receptors and their expression on primary afferent neurons}

$\mathrm{P} 2 \mathrm{X}$ receptors are cation channels on the plasma membranes that open in response to the binding of extracellular ATP. Seven P2X subunits have been identified and cloned $[1,2]$. These subunits can form a number of functional subtypes of recombinant $\mathrm{P} 2 \mathrm{X}$ receptors in a heterologous expression system $[1,2]$. Biophysical and pharmacological characterization of these $\mathrm{P} 2 \mathrm{X}$ receptor subtypes have been extensively reviewed $[1,2]$. It should be pointed out that the two terms, P2X subunit and P2X subtype, have distinct meanings. The former only refers to a component of a functional P2X receptor; the later is used for a functional $\mathrm{P} 2 \mathrm{X}$ receptor. A functional $\mathrm{P} 2 \mathrm{X}$ receptor can be formed from same P2X subunits (i.e., homomeric P2X receptors) or different subunits (i.e., heteromeric $\mathrm{P} 2 \mathrm{X}$ receptors).

All of the seven $\mathrm{P} 2 \mathrm{X}$ receptor subunits appear to be expressed on primary afferent neurons in the spinal dorsal root ganglia (DRG) and trigeminal ganglia [3, 4]. ATP and other $\mathrm{P} 2 \mathrm{X}$ receptor agonists can evoke membrane currents in many primary afferent neurons. The evoked currents show three distinct phenotypes: Fast current, slow current, and mixed current with both fast and slow

Correspondence to: Dr Jianguo G. Gu, Department of Oral and Maxillofacial Surgery and Diagnostic Sciences, McKnight Brain Institute and College of Dentistry, University of Florida, Box 100416, Gainesville, FL 32610, USA. Tel: +1-352-392-5989; Fax: +1-352-392-7609; E-mail: jgu@dental. ufl.edu components [5-10]. The fast current is manifested by rapid desensitization in the range of milliseconds in the presence of agonists. In contrast, the slow current displays weak or little desensitization in the range of seconds in the presence of agonists. By comparing the findings from primary afferent neurons with those recombinant $\mathrm{P} 2 \mathrm{X}$ receptors, it has been suggested that homomeric $\mathrm{P} 2 \mathrm{X}_{3}$ receptors $\left(\mathrm{P} 2 \mathrm{X}_{3}\right)$ account for fast currents, heteromeric $\mathrm{P} 2 \mathrm{X}$ receptors composed of $\mathrm{P} 2 \mathrm{X}_{2}$ and $\mathrm{P} 2 \mathrm{X}_{3}$ subunits $\left(\mathrm{P} 2 \mathrm{X}_{2}+3\right.$ receptors) account for slow currents, and the coexpression of $\mathrm{P} 2 \mathrm{X}_{3}$ and $\mathrm{P} 2 \mathrm{X}_{2}+3$ receptors account for the mixed currents [11-16]. However, for many DRG neurons slow currents appear to also be mediated by $\mathrm{P} 2 \mathrm{X}$ receptor subtypes other than $\mathrm{P} 2 \mathrm{X}_{2}+3$ receptors [10].

Studies have shown that $\mathrm{P} 2 \mathrm{X}$ receptors can be involved in both peripheral and central sensory signaling and processing $[11,12,17-24]$. In the periphery, ATP may be released as a result of tissue stretch, injury and inflammation, visceral distension, or sympathetic activation [25]. ATP release can excite afferent fibers by the activation of $\mathrm{P} 2 \mathrm{X}$ receptors [25-27]. Behavioral studies indicate that ATP and P2X receptors are involved in both nociceptive and innocuous functions [28-32]. P2X receptors are suggested to play roles in nociception under conditions of acute tissue injury and inflammation. Furthermore, P2X receptors have been implicated in neuropathic pain conditions [19, 33-35]. At central sites in the spinal cord dorsal horn, sensory impulses can release ATP [23], which may arise from afferent central terminals, second-order neurons, or astrocytes [36]. ATP can also be released centrally during spinal cord tissue 
damage and inflammation as a result of numerous disorders in the spinal cord. Centrally released ATP [37] may act on the central terminals of afferent fibers, which may then modulate or directly evoke the release of neurotransmitters from afferent central terminals [23, 24, 38]. This action may represent a major function of ATP and $\mathrm{P} 2 \mathrm{X}$ receptors at the central sites in sensory pathways. $\mathrm{P} 2 \mathrm{X}$ receptors on afferent central terminals have novel and important implications in the centrally initiated sensory signals including neuropathic pain associated with disorders in the spinal cord. Furthermore, P2X receptor-mediated modulation of transmitter release at afferent central terminals can also be a novel mechanism for the sensitization of sensory inputs from the periphery [39].

\section{$\mathrm{P} 2 \mathrm{X}$ receptor-mediated sensory pathways to different regions of the spinal cord dorsal horn}

Studies on the nociceptive functions of $\mathrm{P} 2 \mathrm{X}$ receptors are still at an early stage. To understand the nociceptive functions of $\mathrm{P} 2 \mathrm{X}$ receptors under both physiological and pathological conditions, it is essential to identify $\mathrm{P} 2 \mathrm{X}$ mediated nociceptive pathways and to know where and how P2X-mediated nociceptive inputs are transmitted and processed in the spinal cord dorsal horn (DH). The dorsal horn, comprising laminae I and II (superficial laminae), III and IV (intermediate part), and V and VI (deep laminae), is the primary central site for processing somatic sensory inputs [40, 41]. Both the superficial and the deep laminae of the $\mathrm{DH}$ are responsible in the reception, processing and transmission of nociceptive information [41-46]. In contrast, the intermediate part of the dorsal horn is mainly involved in processing non-nociceptive information [41].

P2X sensory pathways to the dorsal horn can be studied on spinal cord sections by immunochemistry with P2X antibodies and by synaptic physiology using the patchclamp technique. These approaches are used to determine whether the central terminals of primary afferent fibers express $\mathrm{P} 2 \mathrm{X}$ receptors and, if so, what types of $\mathrm{P} 2 \mathrm{X}$ receptors are expressed and where these $\mathrm{P} 2 \mathrm{X}$-expressing terminals are located in the dorsal horn. These approaches for the study of $\mathrm{P} 2 \mathrm{X}$ purinergic pathways are based on the assumption that if a type of $\mathrm{P} 2 \mathrm{X}$ receptors is expressed at

A

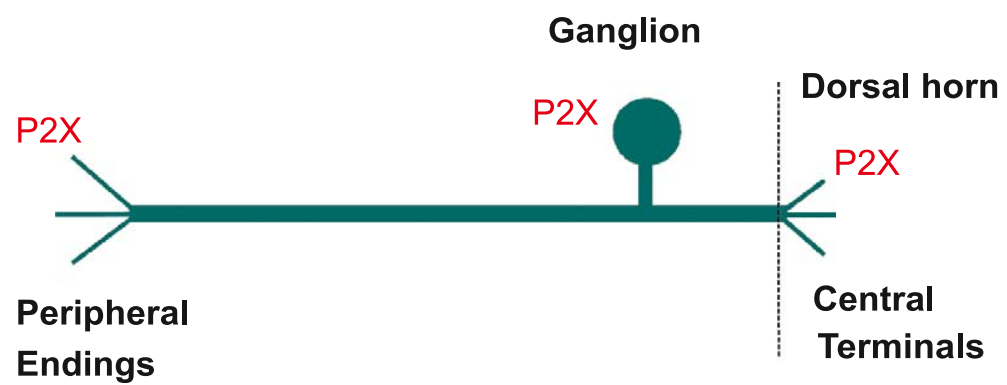

B

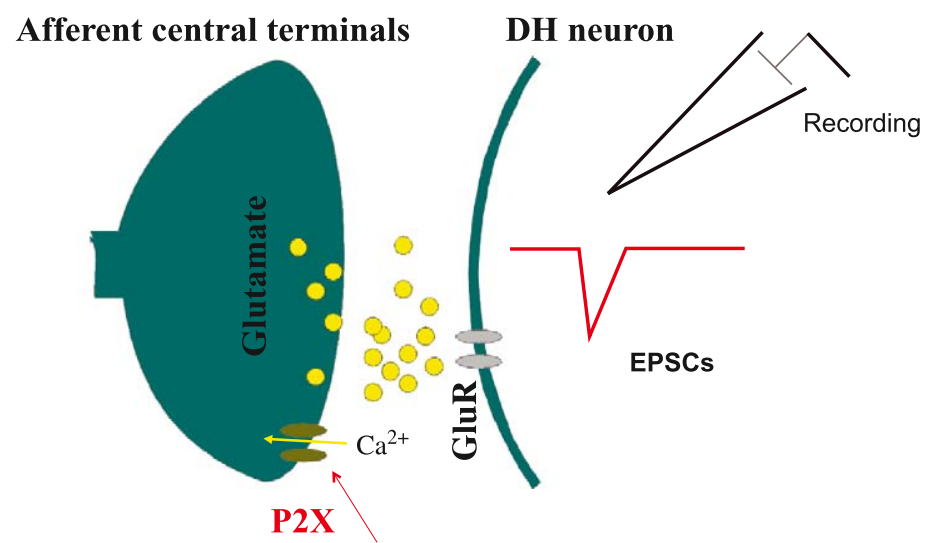

ATP

Figure 1. An assumption of P2X purinergic pathway to the spinal cord dorsal horn and the synaptic physiological approach for the study of P2X purinergic pathway. A) The diagram illustrates a dorsal root ganglion with both peripheral nerve endings and central terminals. The central terminals are within the spinal cord dorsal horn. It is proposed that the expression of a P2X receptor at the central terminal also predicts its presence in other part of the primary afferent fibers including peripheral nerve endings. Thus, $\mathrm{P} 2 \mathrm{X}$ purinergic pathway to the dorsal horn can be mapped by studying $\mathrm{P} 2 \mathrm{X}$ receptors at the central terminals through synaptic physiology or immunochemistry. B) A schematic diagram illustrates the use of synaptic physiology to study P2X purinergic pathway to the dorsal horn using spinal cord slice preparations. Synaptic transmission between afferent central terminals and dorsal horn (DH) neurons is recorded using patch-clamp technique. Activation of $\mathrm{P} 2 \mathrm{X}$ receptors on the central terminals of primary afferent fibers results in the release of glutamate, which in turn activate glutamate receptors (GluR) on dorsal horn neurons and generate excitatory postsynaptic currents (EPSCs). 
the central terminal of a primary afferent fiber, the peripheral site of the afferent fiber also expresses the same type of P2X receptors (Figure 1A). Thus, by studying P2X receptors at the central terminals of primary afferent fibers, one can map the sensory pathways of $\mathrm{P} 2 \mathrm{X}$ purinergic inputs into the spinal cord dorsal horn. These approaches can help us understand the potential functions of different $\mathrm{P} 2 \mathrm{X}$ subtypes in sensory transmission. However, although this assumption is likely to be true for most receptors, it should be noted that membrane receptors may not always be delivered to both ends of a primary afferent fiber.
In immunochemistry studies with $\mathrm{P}_{2} \mathrm{X}_{3}$ antibodies, $\mathrm{P} 2 \mathrm{X}_{3}$ expressing afferent terminals [47-49] appear to be restricted to the inner part of lamina II (lamina IIi). Lamina distribution of afferent fibers that express other P2X subunits remains unclear, although there was a report that showed immunoreactivity of $\mathrm{P}_{2} \mathrm{X}_{1}$ and $\mathrm{P} 2 \mathrm{X}_{2}$ subunits in superfacial lamina as well [50]. Except for $\mathrm{P} 2 \mathrm{X}_{3}$ subunit antibodies, it appears that antibodies for other $\mathrm{P} 2 \mathrm{X}$ receptor subunits have limited usefulness in the spinal cord sections. In addition, a further limitation of immunochemistry is that it only reveals $\mathrm{P} 2 \mathrm{X}$ subunits rather than functional P2X receptors [36].
A

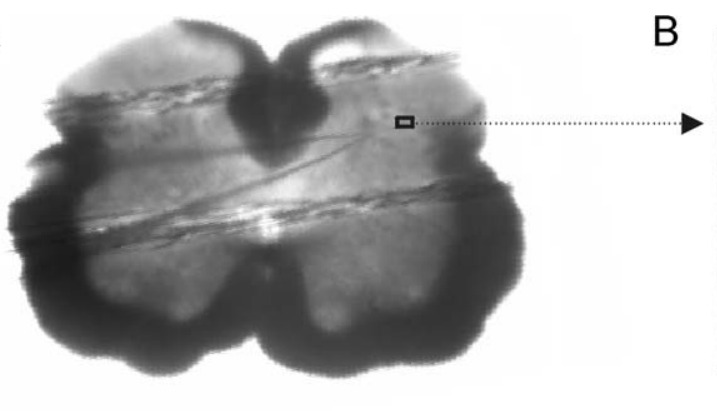

C

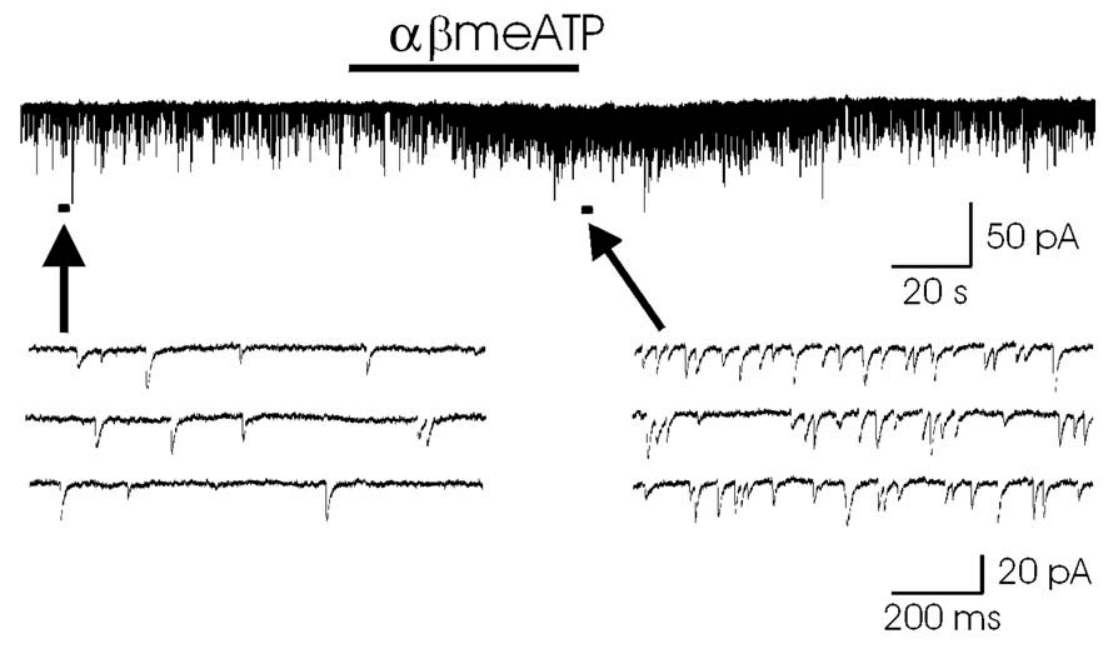

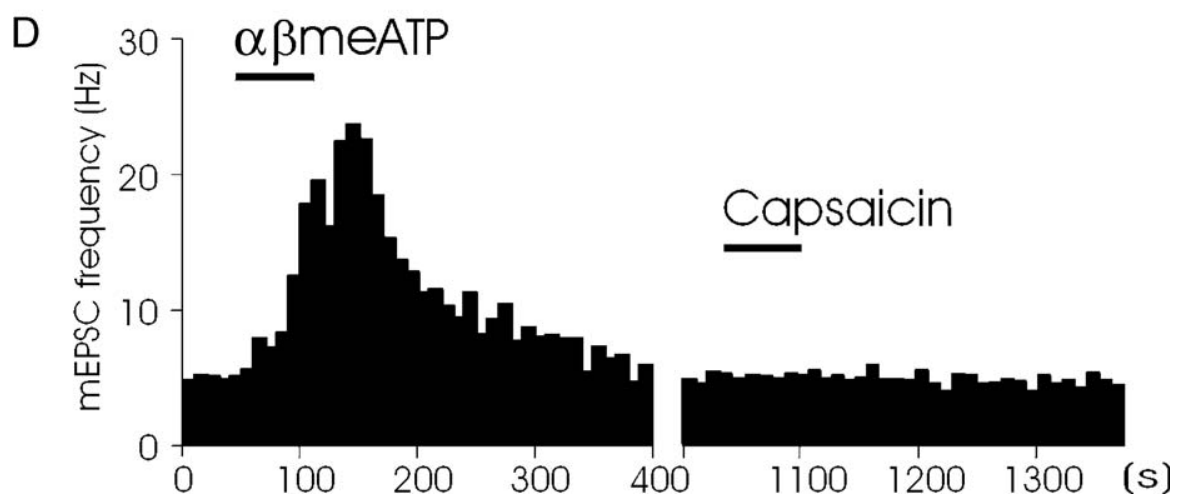

Figure 2. Effects of $\alpha \beta$ meATP on the frequency of miniature excitatory postsynaptic currents recorded from lamina V dorsal horn neurons. A-B) Spinal cord slice preparation viewed under IR-DIC microscope. Lamina regions were identified under $10 \times$ objective (A). A part of a patch electrode is also seen in panel A. The electrode tip is inside tissue about $70 \mu \mathrm{M}$ from the surface, and its lamina location is indicated by a box. A neuron in the box region can be seen under $40 \times$ objective (B, center of the field). The patch electrode is to the left side. C) A trace (top) shows mEPSCs recorded from a lamina V neuron before and following application of $100 \mu \mathrm{M} \alpha \beta$ meATP. Bottom traces show, at an expanded time scale, the mEPSCs before (left three traces) and following (right three traces) $\alpha \beta$ meATP application. D) Histogram shows the time course and degree of the increases in mEPSC frequency after $100 \mu \mathrm{M} \alpha$ BmeATP. It also shows, in the same recording, $2 \mu \mathrm{M}$ capsaicin did not have effect on mEPSCs. Modified and reprinted (with permission) from Nakatsuka et al. [38]. Copyright by the Society for Neuroscience. 
The use of synaptic physiology with patch-clamp recording technique for the study of $\mathrm{P} 2 \mathrm{X}$ purinergic sensory pathways (Figure 1B) provides the opportunity to assess both function and structure in the system in several ways. First, this approach allows one to assess functional P2X receptors that are expressed on primary afferent central terminals. Second, it reveals the effects of P2X purinergic sensory inputs on dorsal horn neurons (i.e., the secondary-order sensory neurons within the dorsal horn). Third, it allows one to characterize neuronal circuits that are involved in processing $\mathrm{P} 2 \mathrm{X}$ purinergic sensory inputs within the dorsal horn. To this end, we have applied patchclamp recording technique to the spinal cord slice preparations to assess the effects of $\mathrm{P} 2 \mathrm{X}$ receptor activation on monosynaptic and polysynaptic transmission from primary afferent fibers to dorsal horn neurons located in a number of lamina regions. We have found that P2X agonists increased monosynaptic transmission from afferent central terminals to the dorsal horn neurons located in lamina V (Figure 2) and lamina II [23, 24, 38]. The original aim of these studies was to explore the role of presynaptic $\mathrm{P} 2 \mathrm{X}$ receptors, i.e., $\mathrm{P} 2 \mathrm{X}$ receptors at the central terminal of primary afferent fibers in modulating glutamate release from P2X-expressing afferent central terminals. However, based on our assumption as illustrated in Figure 1, presynaptic P2X receptor-mediated increases of monosynaptic transmission have also revealed sensory pathways from some P2X-expressing afferent fibers to dorsal horn neurons in these regions (also see [36]). Recordings from lamina $\mathrm{V}$ neurons demonstrated that $\mathrm{P} 2 \mathrm{X}$ receptor agonists produced a prolonged increase of monosynaptic transmission to the majority of lamina $\mathrm{V}$ neurons (Figure 2; $[23,24])$. This finding suggests the wide expression of P2X receptors at the central terminals of these afferent fibers (Figure 3). These afferent fibers have been found to be A $\delta$ afferent fibers and insensitive to capsaicin (Figures 2 and 3), a noxious stimulant that has been commonly used to identify nociceptive afferent fibers. Pharmacological studies have suggested that the $\mathrm{P} 2 \mathrm{X}$ receptors expressed on these capsaicin-insensitive A $\delta$ afferent terminals were not $\mathrm{P} 2 \mathrm{X}_{3}$ or $\mathrm{P} 2 \mathrm{X}_{2}+3$ subtypes but were more likely to be $\mathrm{P} 2 \mathrm{X}_{1+5}$ or $\mathrm{P} 2 \mathrm{X}_{4+6}$ subtypes $[10,38]$. One potential function of this $\mathrm{P} 2 \mathrm{X}$ purinergic sensory pathway may be to transmit sensory information of mechanical stimuli, as based on sensory physiology of $\mathrm{A} \delta$-afferent fibers that innervates lamina $\mathrm{V}$ of the spinal cord dorsal horn. Currently, it is unclear whether this $\mathrm{P} 2 \mathrm{X}$ purinergic sensory pathway is directly involved in nociceptive transmission due to its lack of capsaicin sensitivity. However, nociceptive afferent fibers can also be capsaicin-insensitive. Interestingly, we have found that this ATP-sensitive/capsaicin-insensitive $\mathrm{P} 2 \mathrm{X}$ purinergic pathway has convergence and temporal summation with a capsaicin-sensitive input that is polysynaptically transmitted to lamina $\mathrm{V}$ neurons (Figure 3; [24]). This convergence may suggest that this ATPsensitive/capsaicin-insensitive $\mathrm{P} 2 \mathrm{X}$ purinergic pathway has interaction with nociceptive input.

In contrast to lamina $\mathrm{V}$, many lamina II neurons are monosynaptically contacted by $\mathrm{P}_{2} \mathrm{X}_{3}$-expressing afferent

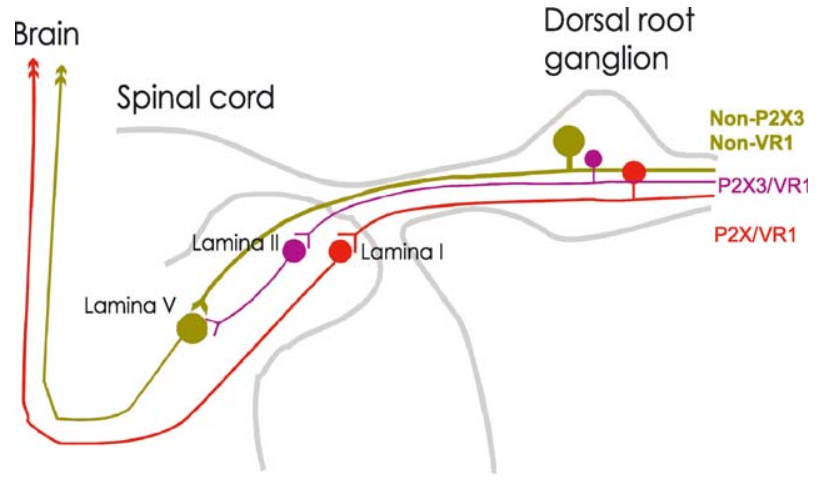

Figure 3. P2X-purinergic sensory pathways to the dorsal horn of the spinal cord. The schematic diagram illustrates three P2X-purinergic sensory pathways to laminas I, II, and V of the dorsal horn. The pathway to lamina II is the afferent fibers expressing both $\mathrm{P} 2 \mathrm{X} 3$ and VR1 receptors. The P2X receptor subtypes of two other pathways had pharmacological properties distinct from $\mathrm{P} 2 \mathrm{X} 3$ containing receptors.

fibers ([38], Figure 3). This result is consistent with immunochemistry of $\mathrm{P} 2 \mathrm{X}_{3}$ subunit distribution in lamina II. These $\mathrm{P} 2 \mathrm{X}_{3}$-expressing afferent fibers also express VR1 receptors $[47,51]$ and are sensitive to capsaicin. Thus, this $\mathrm{P}_{2} \mathrm{X}_{3}$ sensory pathway may be directly involved in transmitting noxious signals. Consistent with this idea, previous studies have shown the nociceptive function of $\mathrm{P}_{2} \mathrm{X}_{3}[35,52-54]$. The ATP-sensitive/capsaicin-sensitive pathway to lamina II was shown to converge to lamina $\mathrm{V}$ neurons through polysynaptic transmission ([24], Figure 3). This may mediate the spatial and temporal sensory summation and subsequent hyperactivity in deep laminae, a potential mechanism of hyperalgesia.

Another important region for pain transmission, processing, and the development of pathological pain is lamina I of the dorsal horn. Due to technical difficulties in performing electrophysiological recordings in lamina I region, there is no report on whether $\mathrm{P} 2 \mathrm{X}$-mediated sensory signals are transmitted to and processed in this important nociceptive region. Our recent experiments performed in lamina I show that some afferent fibers innervating lamina I neurons also express $\mathrm{P} 2 \mathrm{X}$ receptors at their central sites (Figure 3, unpublished result, presented at the Purines 2004 meeting). These afferent fibers are capsaicin-sensitive fibers, suggesting that this is a nociceptive P2X purinergic pathway to the spinal cord dorsal horn. These $\mathrm{P} 2 \mathrm{X}$ receptors are less likely to be $\mathrm{P} 2 \mathrm{X}_{3}$ containing subtypes based on the restricted lamina IIi distribution of $\mathrm{P}_{2} \mathrm{X}_{3}$-expression afferent central terminals [47, 51]. It would be interesting to identify the P2X subtype or subtypes and to see whether it can be a selective target for the control of pain conditions.

\section{Concluding remarks}

The map of P2X purinergic sensory input to different laminas of the spinal cord dorsal horn helps in understanding the sensory functions of $\mathrm{P} 2 \mathrm{X}$ receptors. Under pathological conditions, the destination of $\mathrm{P} 2 \mathrm{X}$ purinergic 
sensory input in different laminas may be altered due to an aberrant expression of $\mathrm{P} 2 \mathrm{X}$ receptors on primary afferent fibers $[34,55]$. This can be a potential mechanism by which $\mathrm{P} 2 \mathrm{X}$ receptors are involved in abnormal sensations such as mechanical allodynia.

\section{Acknowledgements}

The authors thank Dr T. Nakatsuka, K. Tsuzuki, M. Chen, and other members in the laboratory for their hard work on the P2X project. This work was supported by a NIH grant NS38254 and an ONR N00014-01-1-0188 to J.G.G.

\section{References}

1. Khakh BS, Burnstock $\mathrm{G}$, Kennedy $\mathrm{C}$ et al. International union of pharmacology. XXIV. Current status of the nomenclature and properties of P2X receptors and their subunits. Pharmacol Rev 2001; 53: 107-18.

2. North RA. Molecular physiology of P2X receptors. Physiol Rev 2002; 82: 1013-67.

3. Collo G, North RA, Kawashima E et al. Cloning of P2X5 and P2X6 receptors and the distribution and properties of an extended family of ATP-gated ion channels. J Neurosci 1996; 16: 2495-507.

4. Xiang Z, Bo X, Burnstock G. Localization of ATP-gated P2X receptor immunoreactivity in rat sensory and sympathetic ganglia. Neurosci Lett 1998; 256: 105-8.

5. Burgard EC, Niforatos $\mathrm{W}$, van Biesen $\mathrm{T}$ et al. $\mathrm{P} 2 \mathrm{X}$ receptor-mediated ionic currents in dorsal root ganglion neurons. J Neurophysiol 1999; 82: $1590-98$.

6. Ueno S, Tsuda M, Iwanaga $\mathrm{T}$ et al. Cell type-specific ATP-activated responses in rat dorsal root ganglion neurons. Br J Pharmacol 1999; 126: 429-36.

7. Li C, Peoples RW, Lanthorn TH et al. Distinct ATP-activated currents in different types of neurons dissociated from rat dorsal root ganglion. Neurosci Lett 1999; 263: 57-60.

8. Petruska JC, Cooper BY, Johnson RD et al. Distribution patterns of different P2X receptor phenotypes in acutely dissociated dorsal root ganglion neurons of adult rats. Exp Brain Res 2000; 134: $126-32$.

9. Petruska JC, Mena N, Nakatsuka T et al. P2X1 receptor subunit immunoreactivity and ATP-evoked fast currents in adult rat dorsal root ganglion neurons. NeuroReport 2000; 11: 3589-92.

10. Tsuzuki K, Ase A, Seguela P et al. TNP-ATP-resistant P2X ionic current on the central terminals and somata of rat primary sensory neurons. J Neurophysiol 2003; 89: 3235-42.

11. Lewis $\mathrm{C}$, Neidhart $\mathrm{S}$, Holy $\mathrm{C}$ et al. Coexpression of $\mathrm{P} 2 \mathrm{X} 2$ and $\mathrm{P} 2 \mathrm{X} 3$ receptor subunits can account for ATP-gated currents in sensory neurons. Nature 1995; 377: 432-35.

12. Cook SP, Vulchanova L, Hargreaves KM et al. Distinct ATP receptors on pain-sensing and stretch-sensing neurons. Nature 1997; 387: 505-8.

13. Radford KM, Virginio C, Surprenant A et al. Baculovirus expression provides direct evidence for heteromeric assembly of P2X2 and P2X3 receptors. J Neurosci 1997; 17: 6529-33.

14. Liu M, King BF, Dunn PM et al. Coexpression of P2X3 and P2X2 receptor subunits in varying amounts generates heterogeneous populations of $\mathrm{P} 2 \mathrm{X}$ receptors that evoke a spectrum of agonist responses comparable to that seen in sensory neurons. J Pharmacol Exp Ther 2001; 296: 1043-50.

15. Burgard EC, Niforatos $\mathrm{W}$, van Biesen $\mathrm{T}$ et al. Competitive antagonism of recombinant $\mathrm{P} 2 \mathrm{X} 2 / 3$ receptors by $2^{\prime}, 3^{\prime}-O-(2,4,6-$ trinitrophenyl) adenosine $5^{\prime}$-triphosphate (TNP-ATP). Mol Pharmacol 2000; 58: 1502-10.
16. Xu GY, Huang LY. Peripheral inflammation sensitizes $\mathrm{P} 2 \mathrm{X}$ receptor-mediated responses in rat dorsal root ganglion neurons. J Neurosci 2002; 22: 93-102.

17. Krishtal OA, Marchenko SM, Pidoplichko VI. Receptor for ATP in the membrane of mammalian sensory neurones. Neurosci Lett 1983; 35: $41-5$.

18. Jahr CE, Jessell TM. ATP excites a subpopulation of rat dorsal horn neurones. Nature 1983; 304: 730-33.

19. Chen CC, Akopian AN, Siviltotti L et al. A P2X purinoceptor expressed by a subset of sensory neurons. Nature 1995; 377: $428-31$.

20. Gu JG, MacDermott AB. Activation of ATP P2X receptors elicits glutamate release from sensory neuron synapses. Nature 1997; 389: $749-53$.

21. Cockayne DA, Hamilton SG, Zhu QM et al. Urinary bladder hyporeflexia and reduced pain-related behaviour in P2X3-deficient mice. Nature 2000; 407: 1011-15.

22. Souslova V, Cesare P, Nebenuis-Oosthuizen D et al. Warm-coding deficits and aberrant inflammatory pain in mice lacking P2X3 receptors. Nature 2000; 407: 1015-17.

23. Nakatsuka T, Gu JG. ATP P2X receptor-mediated enhancement of glutamate release and evoked EPSCs in dorsal horn neurons of the rat spinal cord. J Neurosci 2001; 21: 6522-31.

24. Nakatsuka T, Furue H, Yoshimura M et al. Activation of central terminal vanilloid receptor-1 receptors and alpha beta-methyleneATP-sensitive P2X receptors reveals a converged synaptic activity onto the deep dorsal horn neurons of the spinal cord. J Neurosci 2002; 22: 1228-37.

25. Burnstock G. A unifying purinergic hypothesis for the initiation of pain. Lancet 1996, 347: 1604-5.

26. Burnstock G. P2X receptors in sensory neurones. Br J Anaesth 2000; 84: 476-88.

27. Irnich D, Tracey DJ, Polten J et al. ATP stimulates peripheral axons in human, rat and mouse - differential involvement of $\mathrm{A}(2 \mathrm{~B})$ adenosine and P2X purinergic receptors. Neuroscience 2002; 110: 123-9.

28. Sawynok J, Reid A. Peripheral adenosine $5^{\prime}$-triphosphate enhances nociception in the formalin test via activation of a purinergic P2X receptor. Eur J Pharmacol 1997; 330: 115-21.

29. Dowd E, McQueen DS, Chessell IP et al. P2X receptor-mediated excitation of nociceptive afferents in the normal and arthritic rat knee joint. Br J Pharmacol 1998; 125: 341-6.

30. Tsuda M, Koizumi S, Kita A et al. Mechanical allodynia caused by intraplantar injection of P2X receptor agonist in rats: Involvement of heteromeric P2X2/3 receptor signaling in capsaicin-insensitive primary afferent neurons. J Neurosci 2000; 20: RC90.

31. Wynn G, Rong W, Xiang Z et al. Burnstock G. Purinergic mechanisms contribute to mechanosensory transduction in the rat colorectum. Gastroenterology 2003; 125: 1398-409.

32. Tempest HV, Dixon AK, Turner WH et al. P2X and P2X receptor expression in human bladder urothelium and changes in interstitial cystitis. BJU Int 2004; 93: 1344-8.

33. Novakovic SD, Kassotakis LC, Oglesby IB et al. Immunocytochemical localization of $\mathrm{P} 2 \mathrm{X} 3$ purinoceptors in sensory neurons in naive rats and following neuropathic injury. Pain 1999; 80: 273-82.

34. Tsuzuki K, Kondo E, Fukuoka $T$ et al. Differential regulation of P2X(3) mRNA expression by peripheral nerve injury in intact and injured neurons in the rat sensory ganglia. Pain 2001; 91: 351-60.

35. McGaraughty S, Wismer CT, Zhu CZ et al. Effects of A-317491, a novel and selective $\mathrm{P} 2 \mathrm{X} 3 / \mathrm{P} 2 \mathrm{X} 2 / 3$ receptor antagonist, on neuropathic, inflammatory and chemogenic nociception following intrathecal and intraplantar administration. Br J Pharmacol 2003; 140: $1381-8$.

36. Gu JG. P2X receptor-mediated modulation of sensory transmission to the spinal cord dorsal horn. Neuroscientist 2003; 9: 370-8.

37. Fyffe RE, Perl ER. Is ATP a central synaptic mediator for certain primary afferent fibers from mammalian skin? Proc Natl Acad Sci USA 1984; 81: 6890-3.

38. Nakatsuka T, Tsuzuki K, Ling J et al. Distinct roles of P2X receptors in modulating glutamate release at different primary sensory synapses 
in the dorsal horn of rat spinal cord. J Neurophysiol 2003; 89: 3243 52.

39. Chizh BA, Illes P. P2X receptors and nociception. Pharmacol Rev 2001; 53: 553-68.

40. Rexed B. The cytoarchitectonic organization of the spinal cord in the rat. J Comp Neurol 1952; 94: 415-66.

41. Willis WD Jr, Coggeshall RE. Sensory Mechanisms of the Spinal Cord. New York: Plenum Press 1991.

42. Cervero F. What is a nociceptor-specific (class 3) cell? Pain 1995; 62: 123-5.

43. Dubner R, Bennett GJ. Spinal and trigeminal mechanisms of nociception. Annu Rev Neurosci 1983; 6: 381-18.

44. Mense S. Nociception from skeletal muscle in relation to clinical muscle pain. Pain 1993; 54: 241-89.

45. Schaible HG, Grubb BD. Afferent and spinal mechanisms of joint pain. Pain 1993; 55: 5-54.

46. Ness TJ, Gebhart GF. Visceral pain: A review of experimental studies. Pain 1990; 41: 167-234.

47. Vulchanova L, Riedl MS, Shuster SJ et al. P2X3 is expressed by DRG neurons that terminate in inner lamina. II. Eur J Neurosci 1998; 10: 3470-8.

48. Bradbury EJ, Burnstock G, McMahon SB. The expression of P2X3 purinoreceptors in sensory neurons: Effects of axotomy and glial-derived neurotrophic factor. Mol Cell Neurosci 1998; 12: 256-68.

49. Guo A, Vulchanova L, Wang $\mathrm{J}$ et al. Immunocytochemical localization of the vanilloid receptor 1 (VR1): Relationship to neuropeptides, the P2X3 purinoceptor and IB4 binding sites. Eur J Neurosci 1999; 11: 946-58.

50. Vulchanova L, Arvidsson U, Riedl M et al. Differential distribution of two ATP-gated channels (P2X receptors) determined by immunocytochemistry. Proc Natl Acad Sci USA 1996; 93: 8063-7.

51. Vulchanova L, Riedl MS, Shuster SJ et al. Immunohistochemical study of the $\mathrm{P} 2 \mathrm{X} 2$ and $\mathrm{P} 2 \mathrm{X} 3$ receptor subunits in rat and monkey sensory neurons and their central terminals. Neuropharmacology 1997; 36: 1229-42.

52. Honore $\mathrm{P}$, Kage $\mathrm{K}$, Mikusa $\mathrm{J}$ et al. Analgesic profile of intrathecal $\mathrm{P} 2 \mathrm{X}(3)$ antisense oligonucleotide treatment in chronic inflammatory and neuropathic pain states in rats. Pain 2002; 99: 11-9.

53. Dorn G, Patel S, Wotherspoon $\mathrm{G}$ et al. siRNA relieves chronic neuropathic pain. Nucleic Acids Res 2004; 32: e49.

54. North RA. P2X3 receptors and peripheral pain mechanisms. J Physiol 2004; 554: 301-8.

55. Ramer MS, Bradbury EJ, McMahon SB. Nerve growth factor induces P2X(3) expression in sensory neurons. J Neurochem 2001; 77: $864-75$. 